\title{
GROWTH-PROMOTING EFFECT ON IRON-SULFUR PROTEINS ON AXENIC CULTURES OF ENTAMOEBA DISPAR
}

\author{
KHALIFA S.A.M.*, IMAI E.*, KOBAYASHI S.*, HAGHIGHI A.**, HAYAKAWA E.* \& TAKEUCHI T.*
}

\section{Summary:}

A growth-promoting factor (GPF) that promotes the growth of Entamoeba dispar under axenic culture conditions was found in fractions of mitochondria (Mt), hydrogenosomes $(\mathrm{Hg})$ and chloroplasts (Cp) obtained from cells of six different protozoan, mammalian and plant species. We were able to extract the GPF from the Cp-rich leaf cells of a plant (spiderwort: Commelina communis L.) in an acetone-soluble fraction as a complex of chlorophyll with low molecular weight proteins (molecular weight [MW] approximately 4,600). We also found that on treatment with $0.6 \%$ complexes of 2 -mercapthoethanol (2ME), complexes of chlorophyll-a with iron-sulphur (Fe-S) proteins (e.g., ferredoxins [Fd] from spinach and Clostridium pasteurianum) and noncomplex rubredoxin (Rd) from C. pasteurianum have a growth-promoting effect on $E$. dispar. These findings suggest that $E$. dispar may lack a sufficient quantity of some essential components of Fe-S proteins, such as Fe-S center.

KEY WORDS : growth, mitochondria, hydrogenosomes, chloroplasts, iron-sulphur protein, Entamoeba dispar.

\section{INTRODUCTION}

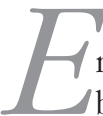
ntamoeba dispar grows well under xenic and monoxenic culture conditions along with enteric bacteria such as Escherichia coli or anaerobic bacteria such as Fusobacterium symbiosum (Clostridium symbiosum ATCC 14940) (Robinson, 1968; Diamond, 1982; Vargas et al., 1990). However, even after the introduction of the axenic yeast extract-iron serum (YI-S) medium for E. dispar (Diamond et al., 1995; Clark, 1995) the axenic cultivation of $E$. dispar remains difficult. Compared with E. dispar, pathogenic E. histolytica, which is closely related to $E$. dispar, easily adapts to the axenic culture medium (TYI-S-33) (Diamond et

\footnotetext{
* Department of Tropical Medicine and Parasitology, School of Medicine, Keio University, Shinjuku-ku, Tokyo, Japan.

** Department of Medical Parasitology and Mycology, School of Medicine Shaheed University of Medical Sciences, Eveen, Teheran 19395, Iran.

Correspondence: Seiki Kobayashi, PhD., Department of Tropical Medicine and Parasitology, School of Medicine, Keio University, 35 Shinanomachi, Shinjuku-ku, Tokyo 160-8582, Japan.

Tel.: +81-3-5363-3761 - Fax: +81-3-3353-5958.

E-mail: skobaya@sc.itc.keio.ac.jp
}

Résumé : LES EFFETS D’ACCÉLÉRATION DE CROISSANCE DES PROTÉINES FER-SOUFRE DANS LA CULTURE AXÉNIQUE D'ENTAMOEBA DISPAR Des facteurs d'accélération de croissance (Growth promoting factor: GPF) favorisant le développement d'Entamoeba dispar ont été détectés dans la composition de la mitochondrie, de I'hydrogénosome et du chloroplaste isolés à partir de six sortes de cellules issues de protozoaires, mammifères et plantes. De plus, les GPF de cellules de mésophile contenant une grande quantité de chloroplaste végétal (Commelina communis L.) ont pu être extraits comme une substance composée de protéines de faible masse moléculaire $(\approx 4600$ ) et de chloroplastes dans la composition acétone-soluble. À partir de ces résultats, nous avons préalablement pu découvrir des effets d'accélération de croissance dans le corps composé de protéines fer-soufre lépinard et ferrédoxine de Clostridium pasteurianum) et de chlorophylle-a traité au 2-mercaptoéthanol 0,6\% et du corps simple rubrédoxine de C. pasteurianum. Ces observations ont suggéré qu'une composante essentielle formant la protéine fer-soufre d'E. dispar (comme noyau fer-soufre) semblait être insuffisante.

MOTS CLÉS : croissance, mitochondrie, hydrogénosome, chloroplaste, protéine fer-soufre, Entamoeba dispar.

al., 1978). Additionally, Entamoeba histolytica is capable of invading the mucosa of the large intestine. We have also developed a new yeast extract-iron-gluconic acid-dihydroxyacetone-serum medium (YIGADHA-S) (Kobayashi et al., 2005) based on the YI-S medium and on the results of an investigation on bacterial metabolic products, and have succeeded in culturing five strains under axenic conditions. However, despite using the YIGADHA-S culture system, the axenic growth of four of five strains of $E$. dispar was found to be very poor, with the exception of one primate-derived strain (CYNO 09: TPC) isolated from a cynomolgus monkey. A further search for useful growth promoting factors (GPFs) revealed that autoclaved $\left(121^{\circ} \mathrm{C}, 15\right.$ minutes) bacteria and more than 20 types of protozoan, mammalian and plant cells containing mitochondria (Mt), hydrogenosomes $(\mathrm{Hg})$ and chloroplasts $(\mathrm{Cp})$ have a significant growth-promoting effect on E. dispar. However, the degree of these growth-promoting effects differs among the GPFs. In the present study, we were able to extract GPF from the Cp-rich leaf cells of a plant (spiderwort: Commelina communis L.) in an acetonesoluble fraction as a chlorophyll complex with low mole- 
cular weight proteins. Significant amounts of iron (Fe), sulphur (S) and molybdenum (Mo) atoms were found in the protein-chlorophyll complex fraction along with the magnesium $(\mathrm{Mg})$ atom of chlorophyll.

Based on these findings, we hypothesized that some common components of Fe-S proteins present in Mt, $\mathrm{Hg}, \mathrm{Cp}$ and bacteria support the growth of E. dispar. This is because in E. dispar, an essential redox Fe-S protein [ferredoxin $(\mathrm{Fd})]$ is expected to be involved in energy metabolism, such as oxidative decarboxylation of pyruvate to acetyl-coenzyme A (acetyl-CoA), which is similar to that found in E. histolytica (McLaughlin \& Aley, 1985).

\section{MATERIALS AND METHODS}

\section{E. DISPAR ISOLATE}

T: $\mathrm{n}$ this study, one human-derived strain of axenically grown E. dispar (AS 16 IR) (Kobayashi et al., 2005) was used to determine the growth promoting effect of Fe-S proteins.

\section{AXENIC CUlTivation OF E. DISPAR}

The YIGADHA-S medium (Kobayashi et al., 2005) containing $15 \%$ heat-inactivated bovine serum was used as the axenic cultivation medium for E. dispar.

\section{Donor cells of Mt, HG, CP AND mitosomes}

The Mt donors are as follows: protozoan parasites: i) $\mathrm{Cri}$ thidia fasciculata (ReF-1, PRR strain, ATCC 50083); ii) Trypanosoma cruzi (Tulahuen strain); iii) Leishmania major (MHOM/SU/73/5-ASKH strain, ATCC 50155); and iv) Acanthamoeba castellanii (ATCC 30011). v) The vertebrate cells used as Mt donors were from the mouse lymphoblast cell line (P388D1, ATCC CCL-46). The Hg donors are as follows: protozoan parasites: vi) Trichomonas vaginalis (KO-11 strain) (Qi et al., 1995) and vii) Trichomonas foetus (Okamoto et al., 1998). viii) Leaves of the spiderwort (Commelina communis L.) were used as the Cp donors. Consisting amitochondrial protozoan parasite mitosomes that are mitochondrial remnant organelles (Tovar et al., 2003) was used as the mitosome donor, ix) Giardia intestinalis (syn. lamblia), (Portland-I strain, ATCC 30888). The bacterium used was Pseudomonas aeruginosa (PA:KEIO strain) (Kobayashi et al., 1998).

\section{PReParation of CELlS}

C. fasciculata and T. cruzi were axenically cultured in liver infusion tryptose (LIT) medium (Gutteridge et al., 1969) supplemented with $10 \%$ foetal bovine serum (FBS). After cultivation for three and seven days res- pectively, $2 \times 10^{7}$ cells of each parasite were harvested by centrifugation ( $650 \mathrm{~g} \times 8$ minutes). The cells of each parasite were washed three times by centrifugation with $10 \mathrm{mM}$ phosphate-buffered saline (PBS) ( $\mathrm{pH} 7.4$ ), and each pellet was suspended in approximately eight times its volume of $50 \mathrm{mM}$ Tris-HCl (pH 7.4). L. major was axenically cultured in Schneider's medium (Gibco ${ }^{\mathrm{TM}}$ ) supplemented with $15 \% \mathrm{FBS}$ at $26^{\circ} \mathrm{C}$ for four days and harvested by centrifugation ( $650 \mathrm{~g} \times 8$ minutes). A. castellanii was axenically cultured in peptone-yeast glucose (PYG) medium (Rowbotham, 1983; ATCC media formulations No. 712) for four days and harvested by centrifugation (650 $\mathrm{g} \times 4$ minutes). The P388D1 cell line was cultured in RPMI 1640 medium (Nissui Pharmaceutical Co., Taito-ku, Tokyo, Japan) supplemented with $10 \%$ FBS for four days and harvested by centrifugation (125 $\mathrm{g} \times 4$ minutes). T. vaginalis and T. foetus were axenically cultured for three days in BI-S-33 medium in which the peptone components of TYI-S33 medium (Diamond et al., 1978) are substituted by Biosate (BBL, Becton Dickinson Co., Cockeysville, Maryland, USA), and harvested by centrifugation (275 $\mathrm{g} \times$ 4 minutes). The $\mathrm{Cp}$-rich fraction from the wild spiderwort (C. communis L.) was isolated. The leaves of wild spiderwort were picked from the private field of Keio University (Tokyo) during the flower season from June to August (2000-2003). Fresh green spiderwort leaves were stripped from the stems, washed with tap water and then with distilled water. The leaves were ground with serum-free RPMI 1640 medium (RPMI) in an earthenware mortar by using a wooden pestle. The resulting leaf cell suspension was filtered through a double thickness gauze to remove the residue. The cell suspension was then washed three times with RPMI by centrifugation ( $440 \mathrm{~g} \times 10$ minutes). P. aeruginosa was cultured in Biosate-Iron broth (Diamond et al., 1978) for three days and harvested by centrifugation (650 $\mathrm{g} \times$ 4 minutes). G. intestinalis was axenically cultured in modified BI-S-33 medium (Keister, 1983) for three days and harvested by centrifugation ( $275 \mathrm{~g} \times 4$ minutes).

\section{Preparation of Mt, Hg AND CP Fractions}

$\mathrm{Mt}, \mathrm{Hg}$ and $\mathrm{Cp}$ rich fractions were prepared as described by Hogeboom (1955), Opperdoes et al. (1984) and Gorham (1955), respectively. Since the methodology for mitosome isolation has not been established, intact cells of $G$. intestinalis were tested for their growthpromoting effect without preparing the mitosome rich fraction. After washing the fractions with RPMI once by centrifugation ( $440 \mathrm{~g} \times 10$ minutes), each fraction was suspended in $2 \mathrm{ml}$ of RPMI. In order to test for their growth-promoting effect under axenic culture conditions, the fractions were sterilized by autoclaving ( $121^{\circ} \mathrm{C}, 15$ minutes), and $0.2 \mathrm{ml}$ of each suspension was added into the YIGADHA-S medium $(5 \mathrm{ml})$. The 
medium was then inoculated with a $0.8 \mathrm{ml}$ suspension of E. dispar (AS16IR strain = AS 16 IR) (final density: 200-2,700 amoebae/ml).

\section{NuPAGE $^{\circledR}$ NovEX 4-12 \% Bis-TRIS GRADIENT PEPTIDE GEL ELECTROPHORESIS AND PREPARATIVE SODIUM DODECYL SULFATE-POLYACRYLAMIDE GEL ELECTROPHORESIS (SDS-PAGE)}

The lyophilized cell fraction of spiderwort was extracted with $20 \%, 40 \%, 80 \%$ and $100 \%$ acetone solutions $(20 \mathrm{mg} / \mathrm{ml})$ for 10 minutes at $4^{\circ} \mathrm{C}$. After centrifugation $\left(17,800 \mathrm{~g} \times 10\right.$ minutes, $\left.4^{\circ} \mathrm{C}\right)$ of each acetone extract, the supernatant was collected. The supernatants that were extracted with $80 \%$ and $100 \%$ acetone solutions were diluted with distilled water to obtain an acetone concentration of $50 \%$. Each supernatant was then concentrated by evaporation by using a SpeedVac system (SVC 100; Savant Instruments, Inc., Farmingdale, New York, USA) until evaporated to dryness. The molecular weight of the proteins in each extract was determined by NuPAGE ${ }^{\circledR}$ Novex 4-12 \% Bis-Tris gradient peptide (Invitrogen Corp., Carlsbad, California, USA) gel electrophoresis.

The bands of complexes of low molecular weight protein with chlorophyll that were detected in the supernatants of $80 \%$ and $100 \%$ acetone extracts were isolated by preparative SDS-PAGE on a $12 \%$ gel in a Mini Prep Cell (Bio-Rad Laboratories, Inc., Hercules, California, USA) electrophoresis unit. SDS-PAGE was performed according to the procedure described by Laemmli (1970). For NuPAGE ${ }^{\circledR}$ (Novex 4-12\% gradient peptide gel $=$ Novex $4-12 \%)$ each dried and concentrated supernatant of the acetone extract was redissolved in the sample buffer with $50 \mathrm{mM}$ dithiothreitol and heated at $70^{\circ} \mathrm{C}$ for 10 minutes to reduce the disulfide bonds. For SDS-PAGE (12\% gel) each supernatant was redissolved in the sample buffer with $1 \%(\mathrm{v} / \mathrm{v}) 2$-mercaptoethanol (2ME) and boiled for four minutes. Following NuPAGE$^{\circledR}$, the gel was stained with 2D-silverstain II (Daiichi Pure Chemicals Co. Ltd., Chuo-ku, Tokyo, Japan).

\section{ASSAY OF THE ACETONE EXTRACTS OF SPIDERWORT LEAF CELLS FOR A GPF}

One millilitre supernatants (obtained after centrifugation; $17,800 \mathrm{~g} \times 10$ minutes, $4^{\circ} \mathrm{C}$ ) of the $20 \%, 40 \%$, $80 \%$ and $100 \%$ acetone extracts of the lyophilized cell fraction of spiderwort $(20 \mathrm{mg} / \mathrm{ml})$ was dialyzed three times against 200-250 volumes of distilled water for 18 hours by using a Spectra/Por ${ }^{\circledR} 3$ (3500 MWCO) dialysis membrane for $18 \mathrm{~h}$; the volume of each extract was adjusted to $2.4 \mathrm{ml}$. Each extract was sterilized by filtration (Sartorius membrane filter; $0.2-\mu \mathrm{m}$ pore size), and $0.2 \mathrm{ml}$ of each extract was added to the YIGADHA$\mathrm{S}$ medium to test the growth-promoting effect of the extract on E. dispar (AS 16 IR).
ANALYSIS USING A SCANNING ELECTRON MICROSCOPY (SEM)/ENERGY DISPERSIVE X-RAY ANALYSER (EDX)-INTEGRATED ANALYSIS SYSTEM

Following the preparative SDS-PAGE, the complexes of chlorophyll with low molecular weight proteins in the $80 \%$ and $100 \%$ acetone-soluble fractions were dialyzed in the same manner as described above. After lyophilization, the dialyzed complexes were examined using an SEM and EDX-integrated analysis system SEM-EDX III Type N/H (Hitachi Science Systems, Ltd., Hitachinaka, Ibaragi, Japan) in the Nihonbashi laboratory, Hitachi HighTechnologies Co., Tokyo, Japan.

\section{PREPARATION OF CHLOROPHYLL-A COMPLEXES WITH PURIFIED IRON-SULPHUR PROTEINS}

Purified Fd from spinach $(1 \mu \mathrm{g} / \mu \mathrm{l}$; Sigma F-3013) and C. pasteurianum ( $1 \mu \mathrm{g} / \mu \mathrm{l}$; Sigma F-7629) and purified rubredoxin (Rd) from C. pasteurianum $(15.7 \mu \mathrm{g} / \mu \mathrm{l}$; Sigma R-2512) were dissolved in $0.6 \% 2 \mathrm{ME} / \mathrm{H}_{2} \mathrm{O}$ (20 $\mu \mathrm{g}$ of $\mathrm{Fd}$ or $31.4 \mu \mathrm{g}$ of $\mathrm{Rd} / 4 \mathrm{ml}$ of $0.6 \% 2 \mathrm{ME}$ ), and the Fd and Rd solutions were dialyzed in the same manner as described above. Purified chlorophyll-a (Sigma C-5753) was dissolved in acetone $(25 \mu \mathrm{g} / 25 \mu \mathrm{l}$ acetone), and after adding $4 \mathrm{ml}$ of distilled water, the solution was dialyzed in the same manner as described above. The Fd and Rd solutions were mixed with dialyzed chlorophyll-a and incubated for 10 minutes at $25^{\circ} \mathrm{C}$. The solutions of chlorophyll-a complexes were then sterilized by filtration, and $0.2 \mathrm{ml}$ of each solution was added to the YIGADHA-S medium to test their growthpromoting effect on E. dispar AS 16 IR.

\section{STATISTICAL ANALYSIS OF GROWTH-PROMOTING EFFECT} ON E. DISPAR

All experiments for testing growth-promoting effect were repeated at least twice. The data of each experiment were subjected to one-way analysis of variance (ANOVA) with Dunnett's multiple comparison post hoc test; the levels of statistical significance were taken as $p<0.05$ and $p<0.01$.

\section{RESULTS}

T The Mt, $\mathrm{Hg}$ and $\mathrm{Cp}$ isolated from eight different types of cells were tested to determine whether they promoted the growth of axenically grown E. dispar AS 16 IR. The intact cells of G. intestinalis and $P$. aeruginosa were also tested for the same. A growthpromoting effect was apparently observed for every fraction except for the fraction of intact cells of G. intestinalis. Apparently, the intact cells of E. histolytica (HM1: IMSS clone 6 strain) containing mitosomes (LeonAvila \& Tovar, 2004) also did not produce a 
growth-promoting effect (data not shown). Although the growth-promoting effect of the two fractions of Mt from $T$. cruzi and the $\mathrm{Hg}$ fraction from $T$. vaginalis retained the statistically significant difference by Dunnett's test $(p<0.05)$, the growth-promoting effect of the other six fractions containing $\mathrm{Mt}, \mathrm{Hg}$ and $\mathrm{Cp}$ was significantly different $(p<0.01$ or $p<0.05)$. In particular, the effect of the $\mathrm{Cp}$ fraction from spiderwort exceeded that of the intact cells fraction of $P$. aeruginosa as shown in Figure 1. Thus, it was concluded that some of the $\mathrm{Mt}, \mathrm{Hg}$ and $\mathrm{Cp}$ fractions, which were obtained under appropriate conditions as well as the intact bacterial cells contain a GPF.

Acetone extraction was used to obtain a water-soluble GPF from Cp-rich leaf cells of some plant species (e.g., spiderwort, cherry and morning glory), which have sufficiently strong leaf-cell membranes that can withstand the leaf crushing and cell isolation process. Figure 2 shows the results obtained on testing the $0 \%, 20 \%$, $40 \%, 80 \%$ and $100 \%$ acetone-soluble fractions from lyophilized Cp-rich leaf cells of spiderwort for a growthpromoting effect. The results showed that the $20 \%$ and $80 \%$ acetone-soluble fractions had a stronger growthpromoting effect than the other acetone-soluble fractions $(0 \%, 40 \%$ and $100 \%)$. The growth-promoting effects of the $20 \%$ and $80 \%$ acetone-soluble fractions were statistically significant at $p<0.01$ (Dunnett's test); however, the effects of the $0 \%, 40 \%$ and $100 \%$ acetone-soluble fractions were retained at $p<0.05$. The silverstain NuPAGE ${ }^{\circledR}$ analysis of these acetone-soluble fractions yielded a distinct dense protein band (MW 4600) that was common to the $20 \%, 40 \%, 80 \%$ and $100 \%$ acetone-soluble fractions. The intensity of the bands of the $20 \%$ and $80 \%$ acetone-soluble fractions were stronger than the bands of the other acetone-soluble fractions (40\% and $100 \%$ ) (Fig. 3). These results indicated that the efficacy of the growth-promoting effect was correlated with the intensity of the low molecular weight protein band (Figs 2, 3). The band of the complex of the chlorophyll with low molecular weight proteins (green colour) present in both the $80 \%$ and $100 \%$ acetone-soluble fractions was obtained by SDSpreparative electrophoresis; both the fractions showed a growth-promoting effect on E. dispar AS 16 IR (data not shown). The result showed that the band of the complex of chlorophyll with low molecular weight proteins, which was present in the acetone-soluble fractions, contained a GPF. The reduction in the intensity of the low molecular weight protein bands obtained by using the $40 \%$ acetone-soluble fraction was considered to be caused by the incomplete solubility of chlorophyll. Some protein parts are believed to be precipitated together with the insoluble chlorophyll when extraction is performed with an intermediate concen-

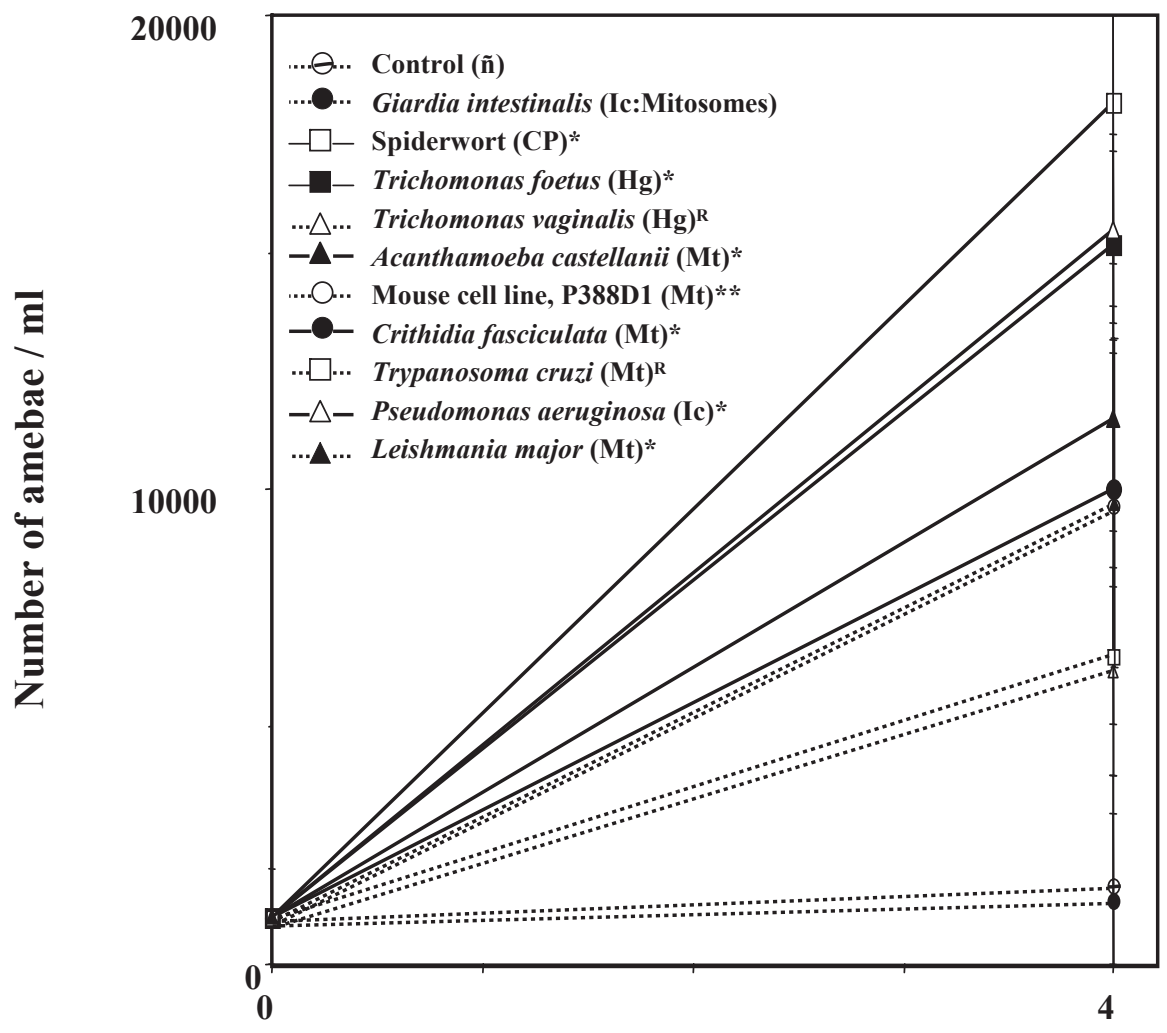

Fig. 1. - The effect of intact cells (Ic) and the fractions of mitochondria (Mt), chloroplasts (Cp) and hydrogenosomes $(\mathrm{Hg})$ from ten types of cells, including bacterial, mammalian, plant and protozoan cells, on the growth of Entamoeba dispar.

The cellular components were sterilized by autoclaving at $121^{\circ} \mathrm{C}$ for 15 minutes. The growth kinetics of the E. dispar AS 16 IR strain in the YIGADHA-S medium are shown (mean numbers of amoebae in duplicate cultures are plotted). * **: the mean of the growth-kinetic level was significantly higher than that of the control $(* p<$ 0.01 and $* * p<0.05$ by Dunnett's test). $\mathrm{R}$ : the significant difference was retained by Dunnett's test $(p<0.05)$.

\section{Days}




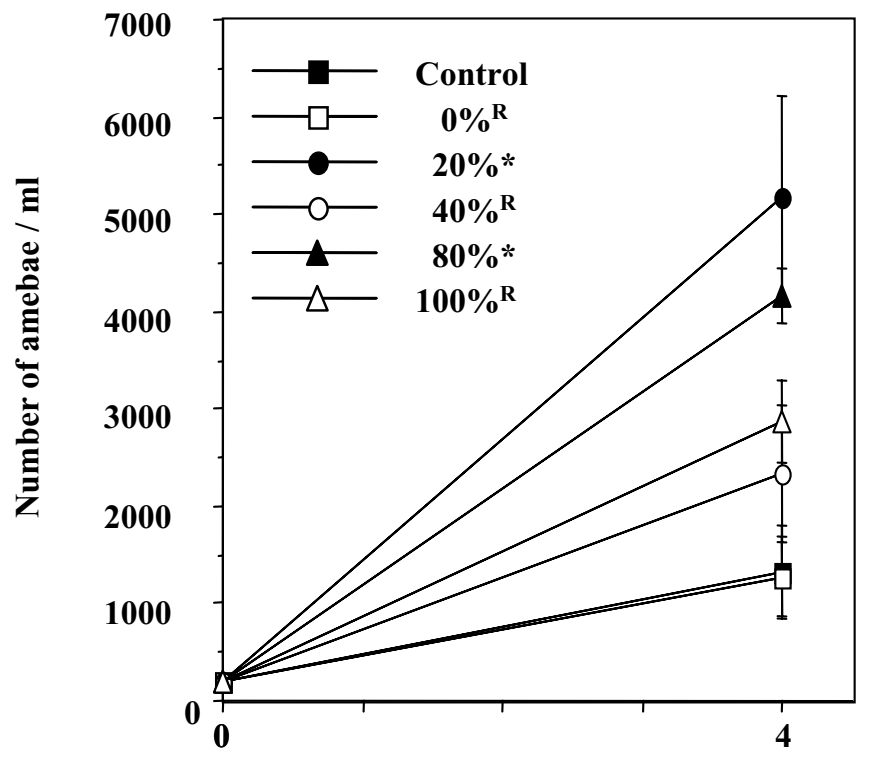

Days
Fig. 2. - Effect of soluble fractions of spiderwort Cp-rich leaf cells extracted with five different concentrations of acetone $(0 \%, 20 \%$, $40 \%, 80 \%$ and $100 \%)$ on the growth of E. dispar.

The growth kinetics of the E. dispar AS 16 IR strain in the YIGADHA-S medium are shown (mean numbers of amoebae in duplicate cultures are plotted). *: the mean of the growth-kinetic level was significantly higher than that of the control $(* p<0.01$ by Dunnett's test). R: the significant difference was retained by Dunnett's test $(p<0.05)$. tration of acetone such as $40 \%$. As compared to an $80 \%$ acetone concentration, the $100 \%$ concentration of acetone was considered to be slightly severe for the extraction of the low molecular weight proteins without

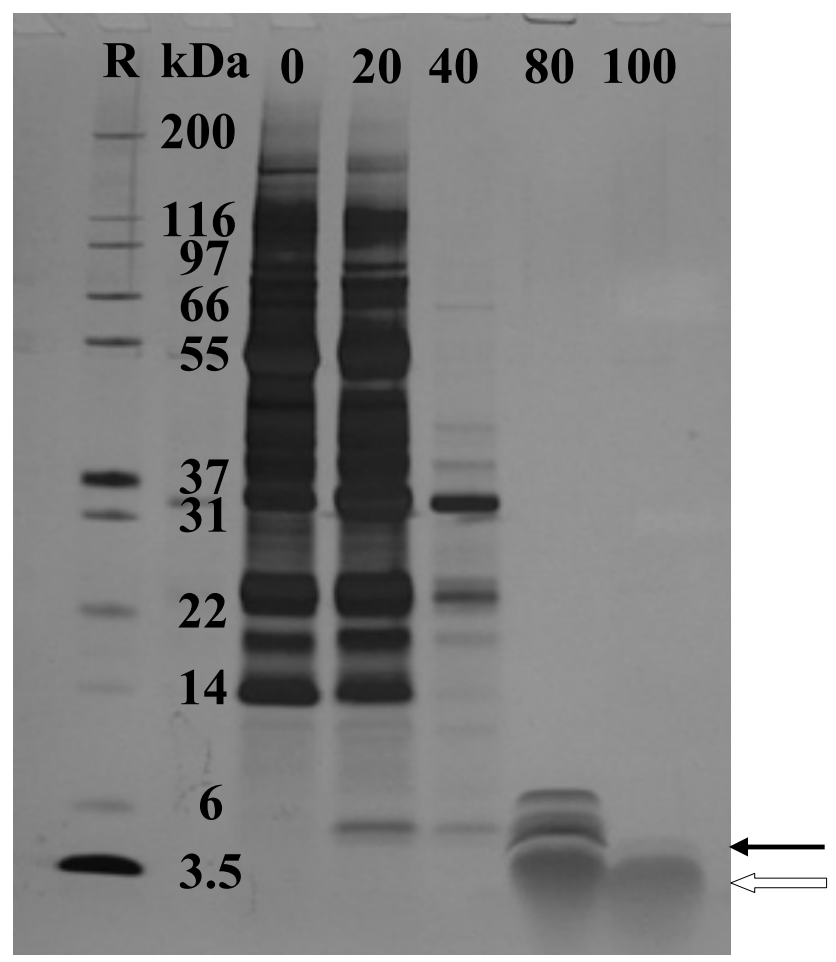

Fig. 3. - NuPAGE ${ }^{\circledR}$ (Novex 4-12\%) of five acetone-soluble fractions of spiderwort $\mathrm{Cp}$-rich leaf cells extracted with different concentrations of acetone ( $\%$, $20 \%, 40 \%, 80 \%$ and $100 \%)$.

Molecular mass markers $(\mathrm{M})$ are shown on the left. $\longleftarrow$ : acetonesoluble low molecular weight protein bands were isolated from the $20 \%, 40 \%, 80 \%$ and $100 \%$ acetone-soluble fractions. $๒$ : broad green band of chlorophyll. decreasing the activity of a GPF. As a result, the intensity of the low molecular weight protein bands obtained by using the $40 \%$ and $100 \%$ acetone-soluble fraction was believed to be reduced.

The SEM/EDX-integrated analysis system revealed that the low molecular weight protein band contained Fe, $\mathrm{S}$ and Mo atoms along with the $\mathrm{Mg}$ atom of chlorophyll (Figs 4, 5). We believed that Fd present in $\mathrm{Cp}$ is a type of $\mathrm{Fe}-\mathrm{S}$ protein containing $\mathrm{Fe}$ and $\mathrm{S}$ atoms. In order to confirm the growth-promoting effect of $\mathrm{Fd}$, we examined the effects of purified spinach Fd (MW 12,000), C. pasteurianum Fd (MW 6,000) and purified C. pasteurianum Rd (MW 19,000) on the growth of E. dispar AS 16 IR. The analysis revealed that $0.6 \%$ 2ME-treated C. pasteurianum $\mathrm{Rd}$ and each of the watersoluble chlorophyll-a complexes with $0.6 \%$ 2ME-treated spinach $\mathrm{Fd}$ and $C$. pasteurianum $\mathrm{Fd}$ have a growthpromoting effect on $E$. dispar AS 16 IR with a statistically significant difference $(p<0.01)$ (Fig. 6). The noncomplexed $\mathrm{Fd}$ from spinach and from $C$. pasteurianum treated with $0.6 \% 2 \mathrm{ME}$ also had a slight growth-promoting effect when compared with the growth kinetics of the control with or without chlorophyll-a; however, these growth-promoting effects were retained $(\mathrm{p}<$ $0.05)$.

These results suggest that the GPF in the acetonesoluble fraction of spiderwort Cp-rich leaf cells is the complex of the chlorophyll-a with a component of an Fe-S protein, such as an inorganic Fe-S centre, released by the breakage of disulfide bonds due to treatment with $2 \mathrm{ME}$. The Fe-S redox proteins are commonly found in enteric bacteria (e.g., Fd), mitochondria (e.g., Fe-S proteins in complex I and II), chloroplasts (e.g., Fd) and hydrogenosomes (e.g., Fd); however, there are diffe- 

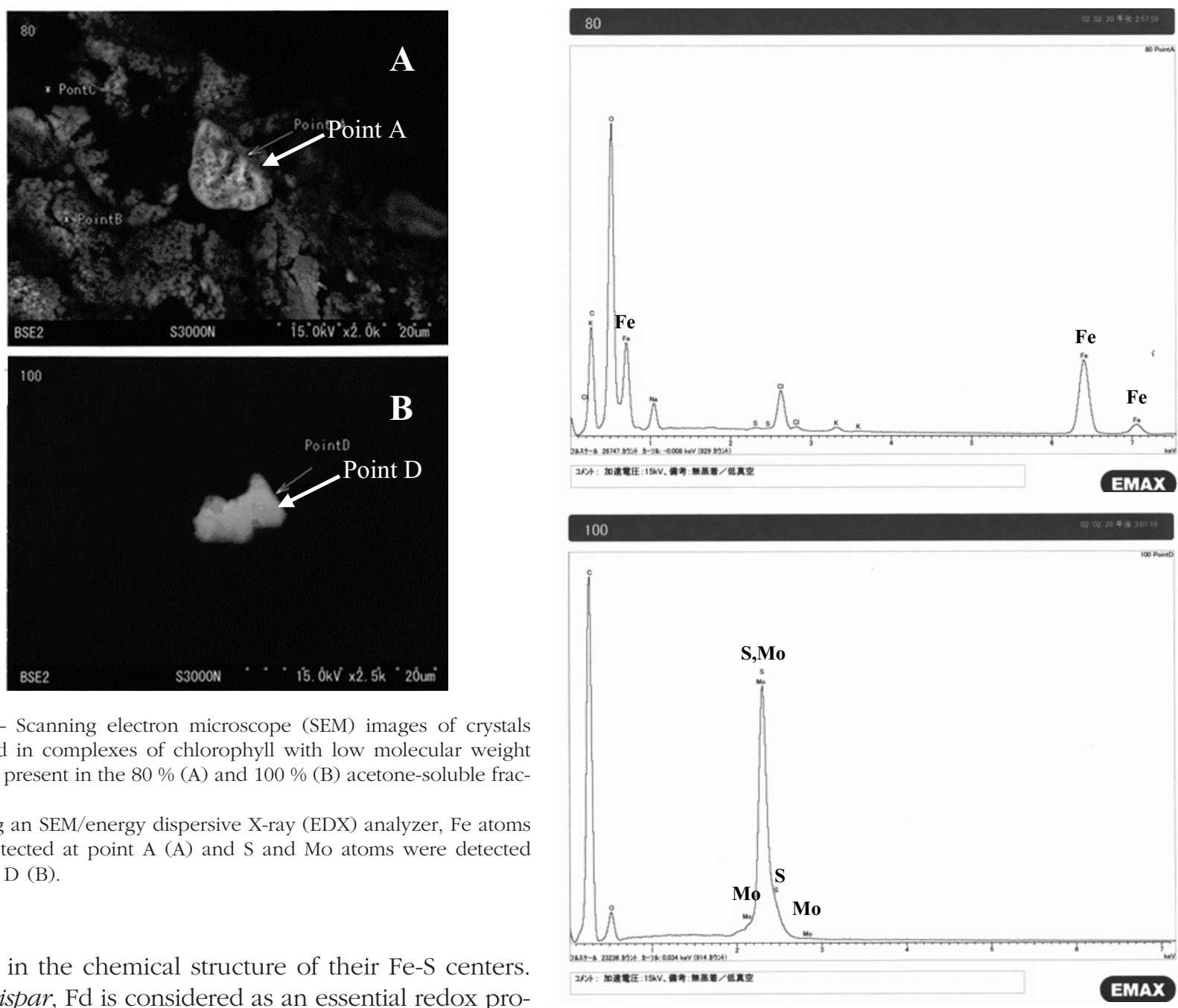

rences in the chemical structure of their Fe-S centers. In E. dispar, $\mathrm{Fd}$ is considered as an essential redox protein involved in energy metabolism, similar to that in E. histolytica, although neither species contains Mt. These findings suggest that $E$. dispar grown under axenic culture conditions may lack a sufficient quantity of some essential component of the Fe-S proteins (e.g., Fe-S centre).

The growth-promoting effect of the GPF was tested on three other strains of $E$. dispar (SAW 1734R clone AR, AS 2 IR and CYNO 16:TPC), (Koyabashi et al., 2005); it was confirmed that the GPF produced the same effect on their growth (data not shown).

\section{DISCUSSION}

P reviously, we designed the YIGADHA-S medium (Kobayashi et al., 2005) for axenic cultivation of E. dispar. It contains dihydroxyacetone (DHA) that has a significant growth-promoting effect on E. dispar. DHA is a ketotriose and functions as a sugar source for E. dispar; therefore, it is considered to be directly metabolized to DHA phosphate, which is an intermediary metabolite in the Embden-Meyerhof-Parnas gly-

Fig. 5. - Specific peaks of the Fe atom at point A (Fig. 3) and S and Mo atoms at point D (Fig. 3) detected in the complexes of chlorophyll with low molecular weight proteins in the $80 \%$ (A) and $100 \%$ (B) acetone-soluble fractions by using an SEM/EDX analyzer.

colytic pathway. However, the growth of E. dispar was poor despite the presence of DHA.

In the present study, a GPF was detected in the autoclaved $\mathrm{Mt}, \mathrm{Hg}$ and $\mathrm{Cp}$ fractions and in intact bacteria and was demonstrated to show a growth-promoting effect on E. dispar. However, the efficacy of each GPF from these organelles varied under different conditions. Prior to the present study, detection of a GPF from trophozoites of E. histolytica (HM-1:IMSS clone 6 strain) was attempted. Since E. histolytica is genetically closely related to $E$. dispar, it contains an abundance of Fe-S proteins, such as Fd, which are only stable under anaerobic conditions, and it contains mitochondrial remnant mitosomes (Leon-Avila \& Tovar, 2004). However, neither the intact cells nor any extract from the cells could promote the growth of E. dispar AS 16 IR (data not shown). One reason for the failure to extract a GPF from E. histolytica trophozoites may be the fragility of 


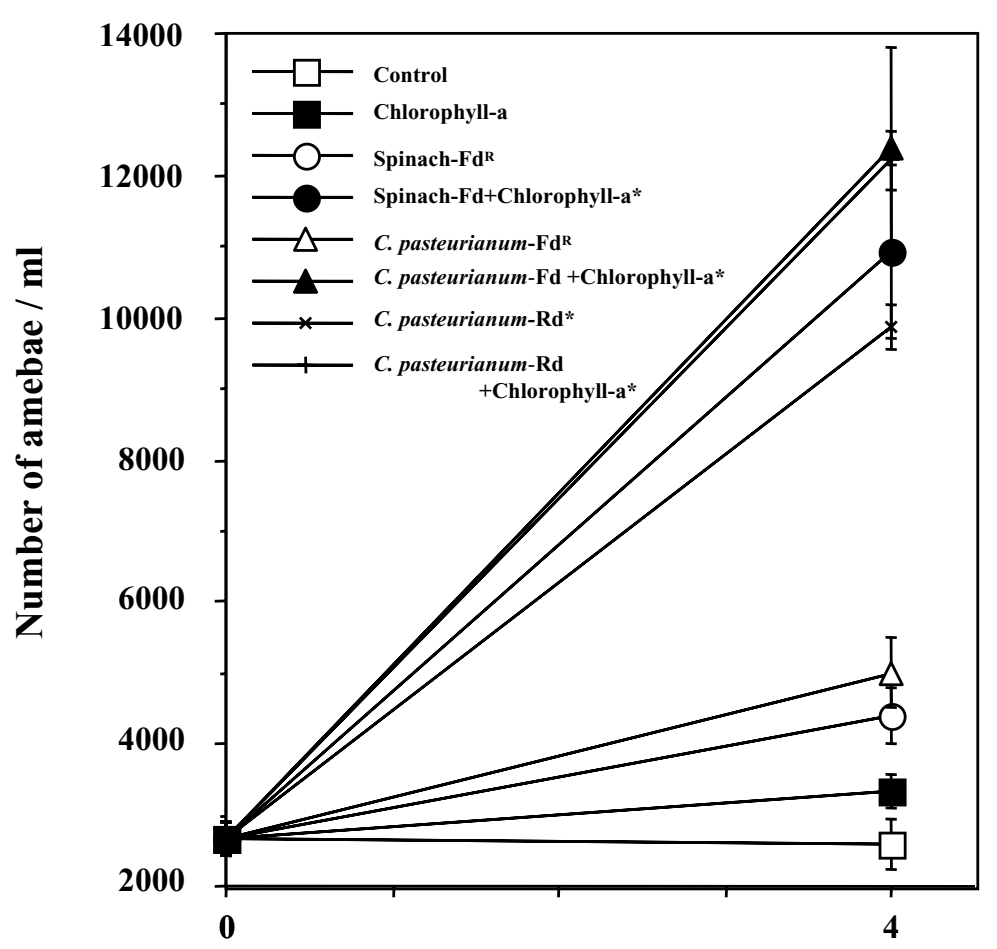

Fig. 6. - Effect of chlorophyll-a ( $-\boldsymbol{-}$ ), $0.6 \%$ 2MEtreated spinach ferredoxin $(\mathrm{Fd})(-\mathrm{O}-)$, Clostridium pasteurianum $\mathrm{Fd}(-\neg)$ and C. pasteurianum rubredoxin (Rd) $(*)$, and complexes of chlorophyll a with spinach $\mathrm{Fd}(-\mathbf{-})$, C. pasteurianum $\mathrm{Fd}(\boldsymbol{-})$ and $C$. pasteurianum $\mathrm{Rd}(\boldsymbol{\longrightarrow})$ on the growth of E. dispar, and control ( $\square-)$.

The growth kinetics of the E. dispar AS 16 IR strain in the YIGADHA-S medium are shown (mean numbers of amoebae in duplicate cultures are plotted). *: the mean of the growth-kinetic level was significantly higher than that of the control (" $p<0.01$ by Dunnett's test). R: the significant difference was retained by Dunnett's test $(p<$ 0.05).

\section{Days}

the cell membrane and organelles (e.g.,mitosomes) similar to that of the spinach leaf cells. The GPF was assumed to be composed of a heat-stable substance and some other common simple inorganic substances. It was feasible to isolate the GPF from acetone-soluble fractions of Cp-rich leaf cells as bands of low molecular weight proteins complexed with chlorophyll containing $\mathrm{Fe}, \mathrm{S}$ and Mo atoms.

The results of this study indicate that the protein bands may be derived from Fe-S (e.g., Fd) or Mo-Fe-S proteins [e.g., molybdoferredoxin, which is a common component of nitrogenase (present in rhizobium species)]. It appears that the GPF requires to form a complex with chlorophyll because the growth-promoting effects of purified $\mathrm{Fd}$ from spinach, C. pasteurianum and E. histolytica strain HM-1: IMSS clone 6 (the Fd consists of $4 \mathrm{Fe}-4 \mathrm{~S}$ centre) on E. dispar AS 16 IR were not remarkable (data not shown). We found that the complex of chlorophyll-a with $0.6 \%$ 2ME-treated Fd containing a $2 \mathrm{Fe}-2 \mathrm{~S}$ centre from spinach and that containing $4 \mathrm{Fe}-4 \mathrm{~S}$ centre from $C$. pasteurianum have a growth-promoting effect on E. dispar AS 16 IR. This effect was also observed with $0.6 \% 2 \mathrm{ME}$-treated Rd, which has the most simple Fe-S centre ( 1 Fe and 4 cysteine-residues without inorganic S), without chlorophyll-a. It is not clearly understood why complex formation must occur between chlorophyll-a and the components (Fe-S centres and cysteine residues) of bacterial and plant Fd to produce a growth-promoting effect is not clearly understood. However, it is considered that the complex of chlorophyll-a with the $\mathrm{Fd}$ component (MW greater than 100,000 by gel permeation chromatography) may be efficiently taken up by amoeba cells as a compact mass by a process, such as pinocytosis, and the complex may be degraded until an appropriate size of the Fe-S compound is obtained. We speculate that the Fe-S compounds are utilized as components of some essential Fe-S proteins such as amoebic Fd, which is an essential redox protein involved in oxidative decarboxylation of pyruvate to acetyl COA in E. dispar; this is similar to that reported in E. histolytica (McLaughlin \& Aley, 1985). It is reported that the amitochondrial protozoan parasite E. histolytica, which is closely related to $E$. dispar, contains numerous fermentation enzymes that are similar to bacterial enzymes, including the pyruvate $\mathrm{Fd}$ oxidoreductase, $\mathrm{Fd}$ and alcohol dehydrogenase E, derived from concomitant enteric bacterial DNA by horizontal transfer (Rosenthal et al., 1997).

We succeeded in developing a more stable axenic cultivation system by adding the complex of chlorophyll with a component of Fe-S protein (e.g., Fd from spiderwort) treated with 2ME to the YIGADHA-S medium. We achieved an improved axenic cultivation system for E. dispar by using cellular components of protozoan, mammalian and plant cells as well as intact bacteria. However, we recognize that it is difficult to develop an axenic cultivation system for $E$. dispar that is at par 
with the well-established cultivation system of E. histolytica for use in biological studies such as biochemical and immunological studies, etc.

\section{ACKNOWLEDGEMENTS}

T The authors thank the staff of Nihonbashi Laboratory, Hitachi High-Technologies Co., Tokyo, Japan for their cooperation in the analysis using the SEM-EDX III Type N/H. This work was supported by a Keio Gijuku Fukuzawa Memorial Fund for the Advancement of Education and Research and a Health Sciences Research Grant-in-Aid for Emerging and Reemerging Infectious Diseases.

\section{REFERENCES}

Clark C.G. Axenic cultivation of Entamoeba dispar Brumpt 1925, Entamoeba insolita Geiman and Wichterman 1937 and Entamoeba ranarum Grassi 1879. Journal of Eukaryotic Microbiology, 1995, 42, 590-593.

Diamond L.S., Harlow D.F. \& Cunnick C.C. A new medium for the axenic cultivation of Entamoeba bistolytica and other Entamoeba. Transactions of the Royal Society of Tropical Medicine and Hygiene, 1978, 72, 431-432.

DiAmOND L.S. A new liquid medium for xenic cultivation of Entamoeba bistolytica and other lumen-dwelling protozoa. Journal of Parasitology, 1982, 68, 958-959.

Diamond L.S., Clark C.G. \& CunNick C.C. YI-S, a casein-free medium for axenic cultivation of Entamoeba histolytica, related Entamoeba, Giardia intestinalis and Trichomonas vaginalis. Journal of Eukaryotic Microbiology, 1995, 42, 277-278.

Gorham P.R. Preparation of chloroplasts and disintegrated chloroplasts, in: Methods in Enzymology vol. I. Colowick S.P. \& Kaplan N.O. (eds), Academic Press, New York, 1955, 22-25.

Gutteridge W.E., Knowler J. \& CoOmbes J.D. Growth of Trypanosoma cruzi in human heart tissue cells and effects of aminonucleoside of puromycin, trypacidin and aminopterin. Journal of Protozoology, 1969, 16, 521-525.

Hogeboom G.H. Fractionation of cell components of animal tissues, in: Methods in Enzymology vol. I. Colowick S.P. \& Kaplan N.O. (eds), Academic Press, New York, 1955, 1619.

KeISTER D.B. Axenic culture of Giardia lamblia in TYI-S-33 medium supplemented with bile. Transactions of the Royal Society of Tropical Medicine and Hygiene, 1983, 77, 487488.

Kobayashi S., Imai E., Haghighi A., Khalifa S.A., Tachibana H. \& TAKEUCHI T. Axenic cultivation of Entamoeba dispar in newly designed yeast extract-iron-gluconic acid-dihydroxyacetone-serum medium. Journal of Parasitology, 2005, 91, $1-4$.

Kobayashi S., Imai E., Tachibana H., Fujiwara T. \& Takeuchi T. Entamoeba dispar: cultivation with sterilized Crithidia fasciculata. Journal of Eukaryotic Microbiology, 1998, 45, 3S-8S.

Kobayashi S., Imai E., Haghighi A., Tachibana H. \& Takeuchi T. Cultivation of Entamoeba dispar: growth-promoting effect of ferredoxin. Archives of Medical Research, 2000, 31 (Suppl.), S210-S211.

LAEMMLI U.K. Cleavage of structural proteins during the assembly of the head of bacteriophage T4. Nature, 1970, 227, 680-685.

Leon-Avila G. \& Tovar J. Mitosomes of Entamoeba histolytica are abundant mitochondrion-related remnant organelles that lack a detectable organellar genome. Microbiology, 2004, 150, 1245-1250.

Mclaughuin J. \& Aley S. The biochemistry and functional morphology of the Entamoeba. Journal of Protozoology, 1985, 32, 221-240.

Okamoto S., Wakui M., Kobayashi H., Sato N., Ishida A., Tanabe M., Takeuchi T., Fukushima S., Yamada T. \& IKeda Y. Trichomonas foetus meningoencephalitis after allogeneic peripheral blood stem cell transplantation. Bone Marrow Transplantation, 1998, 21, 89-91.

Opperdoes F.R., Baudhuin P., Coppens I, de Roe C., Edwards S.W., Weiers P.J. \& Misset O. Purification, morphometric analysis, and characterization of glycosomes (microbodies) of the protozoan hemoflagellate Trypanosoma brucei. Journal of Cell Biology, 1984, 98, 1178-1184.

Qi H.Y., Kobayashi S., Fujiwara T., Nozawa S., Ohta H., Kiguchi K., Tojo R., Kobayashi J., Sumi K., Yano A. \& TAKeUchi T. Occurrence of metronidazole-resistant Trichomonas vaginalis in Japan. Japanese Journal of Parasitology, 1995, 44, 473-480.

Robinson G.L. The laboratory diagnosis of human parasitic amoebae. Transactions of the Royal Society of Tropical Medicine and Hygiene, 1968, 62, 285-294.

Rosenthal B., Mai Z., Caplivski D., Ghosh S., de la Vega H., GraF T. \& SAMUELSON J. Evidence for the bacterial origin of genes encoding fermentation enzymes of the amitochondriate protozoan parasite Entamoeba histolytica. Journal of Bacteriology, 1997, 179, 3736-3745.

Rошвотнам T.J. Isolation of Legionella pneumophila from clinical specimens via amoebae, and the interaction of those and other isolates with amoebae. Journal of Clinical Pathology, 1983, 36, 978-986.

Tovar J., Leon-Avila G., Sanchez L.B., Sutak R., Tachezy J., van der Giezen M., Hernandez M., Muller M. \& Lucoce J.M. Mitochondrial remnant organelles of Giardia function in iron-sulphur protein maturation. Nature, 2003, 426,172176.

Vargas M.A., Isibasi A., Kumate J. \& Orozco E. Non-pathogenic Entamoeba histolytica: functional and biochemical characterization of a monoxenic strain. Molecular and Biochemical Parasitology, 1990, 40, 193-201.

Reçu le 14 juin 2005 Accepté le 4 novembre 2005 